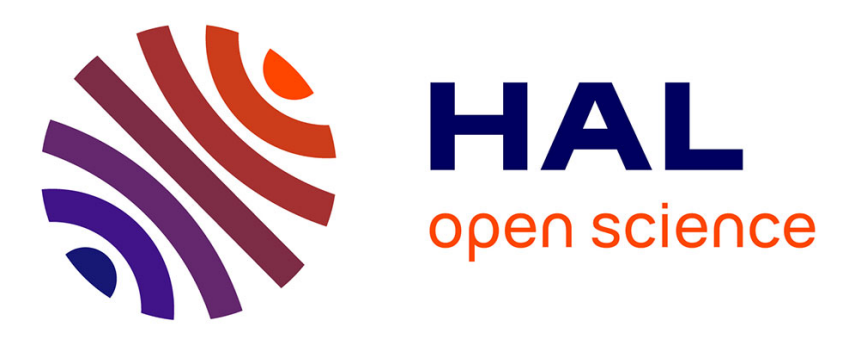

\title{
Physiological variation among western redcedar (Thuja plicata Donn ex D. Don) populations in response to short-term drought
}

\author{
Steven C. Grossnickle, John H. Russell
}

\section{- To cite this version:}

Steven C. Grossnickle, John H. Russell. Physiological variation among western redcedar (Thuja plicata Donn ex D. Don) populations in response to short-term drought. Annals of Forest Science, 2010, 67 (5), 10.1051/forest/2010008 . hal-00883601

\section{HAL Id: hal-00883601 https://hal.science/hal-00883601}

Submitted on 1 Jan 2010

HAL is a multi-disciplinary open access archive for the deposit and dissemination of scientific research documents, whether they are published or not. The documents may come from teaching and research institutions in France or abroad, or from public or private research centers.
L'archive ouverte pluridisciplinaire HAL, est destinée au dépôt et à la diffusion de documents scientifiques de niveau recherche, publiés ou non, émanant des établissements d'enseignement et de recherche français ou étrangers, des laboratoires publics ou privés. 


\title{
Physiological variation among western redcedar (Thuja plicata Donn ex D. Don) populations in response to short-term drought
}

\author{
Steven C. GROSSNICKLE ${ }^{1 *}$, John H. RUSSELL ${ }^{2}$ \\ ${ }^{1}$ CellFor Inc., \#4 6772 Oldfield Rd., Saanichton, BC, V8M 2A3, Canada \\ ${ }^{2}$ Cowichan Lake Research Station, BC Ministry of Forests and Range, P.O. Box 335, Mesachie Lake, BC,V0R 2N0, Canada
}

(Received 23 June 2009; accepted 3 November 2009)

Keywords:

western redcedar population

performance /

gas exchange /

water relations /

drought response

Mots-clés :

performances de populations de thuyas

géants /

échanges gazeux /

relations hydriques /

réponse à la sécheresse

\begin{abstract}
- Variation in the ability of western redcedar (Thuja plicata Donn ex D. Don) populations to withstand water stress may exist because this species is found in coastal and interior biogeoclimatic subzones representing the full range of precipitation regimes in British Columbia, Canada.

- Seven western redcedar populations from locations in British Columbia, representing a wide range of habitat types, were assessed for their gas exchange and water relations response to controlled drought.

- Before drought, population variation occurred in stomatal conductance, net $\mathrm{CO}_{2}$ assimilation rate and intrinsic water use efficiency and the relative water content at turgor loss point. During drought, populations had different responses of net $\mathrm{CO}_{2}$ assimilation to decreasing predawn shoot water potential. After drought, populations differed in stomatal conductance and intrinsic water use efficiency, plus osmotic potential at turgor loss point, osmotic potential at saturation and apparent cuticular transpiration. Western redcedar populations from drier-inland habitats had a lower osmotic potential at turgor loss point, lower relative water content at turgor loss point and lower apparent cuticular transpiration in response to drought than populations from coastal origin with temperate maritime habitat. - Reduction of cuticular water loss and adjustments of cellular water relations in response to drought was found to occur among seven western redcedar populations originating along a precipitation gradient while; there were minimal population differences in the gas exchange response to drought.
\end{abstract}

Résumé - Variations physiologiques dans des populations de thuyas géants (Thuja plicata Donn ex D. Don) en réponse à une sécheresse courte.

- Les variations de capacité à résister au déficit hydrique dans des populations de thuyas géants (Thuja plicata Donn Ex D. Don) apparaissent parce que cette espèce se rencontre dans les sous-zones biogéoclimatiques côtières et de l'intérieur représentant l'éventail complet de régimes de précipitations en Colombie britannique (Canada).

- Sept populations de thuyas géants issues de sites de Colombie britannique, représentant un large éventail des types d'habitats, ont été évaluées pour leurs échanges gazeux et leurs relations hydriques en réponse à une sécheresse contrôlée.

- Avant la sécheresse, une variabilité existait entre populations pour la conductance stomatique, l'assimilation nette de $\mathrm{CO}_{2}$, l'efficience intrinsèque d'utilisation de l'eau et la teneur relative en eau au point de perte de turgescence. Pendant la sécheresse, les populations ont présenté des réponses différentes de l'assimilation nette de $\mathrm{CO}_{2}$ à la baisse du potentiel hydrique de base. Après la sécheresse, les populations différaient en conductance stomatique et efficience intrinsèque d'utilisation de l'eau, mais également en potentiel osmotique au point de perte de turgescence, en potentiel osmotique à saturation et en transpiration cuticulaire apparente. Les populations de thuyas géants des habitats intérieurs les plus secs présentaient un plus faible potentiel osmotique au point de perte de turgescence, une plus faible teneur en eau au point de perte de turgescence et une plus faible transpiration cuticulaire apparente en réponse à la sécheresse que les populations d'origine côtière avec un habitat maritime tempéré.

- Une réduction des pertes d'eau cuticulaires et des ajustements des relations hydriques cellulaires en réponse à la sécheresse ont été trouvés parmi sept populations de thuyas géants originaires de sites se trouvant le long d'un gradient de précipitations, alors qu'il n'y avait que de faibles différences entre populations pour la réponse des échanges gazeux à la sécheresse.

\footnotetext{
* Corresponding author: sgrossnickle@ cellfor.com
} 


\section{INTRODUCTION}

Western redcedar (Thuja plicata Donn ex D. Don) is a tree species that occurs over a wide geographic range in British Columbia, Canada. It spans from coastal regions where it is most productive in the moist maritime environment of the coastal western hemlock $(\mathrm{CWH})$ zone, the wetter soil water regimes of the coastal Douglas-fir (CDF) zone, and it is also found in interior regions where it is a dominant species of the interior cedar-hemlock zone (ICH) (Ketcheson et al., 1991; Nuszdorfer et al., 1991). It is also found in valley basins of the very dry interior Douglas-fir zone (IDF) (Hope et al., 1991). With access to the water table, it can also occur in areas that are too dry for western hemlock (Tsuga heterophylla (Raf.) Sarg.) (Minore, 1990). Such adaptation observations potentially infer genetic variation which is systematic with respect to environmental parameters.

The occurrence of western redcedar in both coastal and interior biogeoclimatic subzones represents the full range of precipitation regimes in British Columbia. This suggests that populations from various habitats may differ in their ability to withstand water stress. Such adaptation may depend on genetic variation among populations of western redcedar (Rehfeldt, 1994). Studies have documented genotypic variation in gas exchange (e.g., Aspelmeier and Leuschner, 2004; Johnsen and Major, 1995; Monson and Grant, 1989) and water relations (e.g., Abrams, 1988; Aspelmeier and Leuschner, 2004; Johnsen and Major, 1999; Parker and Pallardy, 1985) of tree species in relation to their habitat of origin. Although widely distributed in the region under sharply contrasting environmental conditions, western redcedar has been found to vary little genetically in isozymes (e.g., Yeh, 1988), while there is reported population variation in microsatellites (O'Connell et al., 2001). Significant family variation has been shown for western redcedar in growth rates (Russell et al., 2003; Wang and Russell, 2006) and population variation in physiological and morphological traits (Fan et al., 2008; Grossnickle et al., 2005; Rehfeldt, 1994). Some adaptive genetic variation is known to exist between western redcedar populations (Rehfeldt, 1994), though information on the amount and pattern of this variation in relation to precipitation gradients and soil water regimes is minimal.

This study was part of a larger program investigating the adaptive physiology of seven western redcedar populations originating along a precipitation gradient (from east to west) from various biogeoclimatic zones in British Columbia. The overall program objective was to define the physiological and morphological response of these western redcedar populations to summer time soil and atmospheric water conditions. In companion papers, Grossnickle et al. (2005) reports on the gas exchange response and summer-time water use efficiency of the same populations to atmospheric demand under summer time field conditions, while Fan et al. (2008) reports on the morphological development and inherent water-use efficiencies of these populations under long-term moderate drought. The objective of this trial was to describe gas exchange parameters, plus drought tolerance and avoidance parameters of seven western redcedar populations in response to short term drought. Intended application of program findings was to define physiological variables that could be used to assess western redcedar populations when developing a sound gene resource management strategy.

\section{MATERIALS AND METHODS}

\subsection{Plant material}

Western redcedar (Thuja plicata Donn) seeds came from six populations representing zonal associations within biogeoclimatic variants (Pojar et al., 1991) from the west coast to interior wet belt climatic zones at $\sim 49^{\circ}$ north latitude and spans from $116^{\circ}$ to $125^{\circ}$ west longitude (Tab. I). In addition, a population collected near Prince Rupert ( $\sim 54^{\circ} \mathrm{N}$ Lat.) from the coastal cedar-western hemlock biogeoclimatic zone was included in the study. Open-pollinated seeds were collected from five trees within each of the seven populations. Each population assessed in this study came from a combination of four of the five open-pollinated families. Population descriptor data were obtained from Meteorological Service of Canada: 1961-1990 average monthly precipitation data for British Columbia that had been mapped on a $2.5^{\circ}$ by $2.5^{\circ}$ grid using the PRISM climate analysis system and a digital elevation model (Daly et al., 1997).

Seedlings were grown as $1+0$ container (planted in April in a 415B styroblock $^{\mathrm{TM}}$ format; $108 \mathrm{cc}$ volume cavities) stocktype at Cowichan Lake Research Station ( $48^{\circ} 49^{\prime} \mathrm{N}$ Lat. 124 $14^{\prime}$ W Long., $200 \mathrm{~m}$ elevation) under standard cultural practices to ensure rapid development. Seedlings were then placed outdoors in September and treated with a fall watering, fertilization, daylength and temperature regime to allow for fall/winter acclimation. These seedlings were grown under a standard container-nursery cultural regime used in British Columbia, Canada (Van Eerden and Gates, 1990). All populations were grown as part of a homogeneous nursery crop population and had statistically similar height, diameter, shoot and root dry weight, before trial initiation (Fan et al., 2008).

\subsection{Testing environment}

In late winter, each test seedling was potted in a two-litre milk carton. Cartons had two eight $\mathrm{mm}$ diameter drainage holes at their base, and were filled with a 1:1 peat:sand mixture, selected for its slow, even drying pattern. After potting, seedlings were placed in a controlled environment room $\left(22 \pm 3{ }^{\circ} \mathrm{C}\right.$ air temperature, $35 \pm 5 \%$ relative humidity, $2.3 \pm 0.05 \mathrm{kPa}$ vapour pressure deficit, ambient $\mathrm{CO}_{2}$ conditions $\approx 400 \mathrm{ppm}, 16-\mathrm{h}$ photoperiod at $600 \mu \mathrm{mol} \mathrm{m}^{-2} \mathrm{~s}^{-1}$ at seedling height). Seedlings from all populations were randomly positioned and maintained under well-watered conditions for two weeks and the initiation of shoot growth was started before commencement of the experiment.

Test populations (each population $=50$ seedlings or 10 to 12 per family) were divided in half for two watering regimes: (1) continuously well-watered; or (2) exposed to two drought/recovery cycles, consisting of a first dry-down cycle followed by a ten-day wellwatered period and then a second dry-down cycle. Dry-down cycles ended for each population when mean predawn shoot water potential $\left(\Psi_{\text {pd }}\right)$ was $-1.2 \mathrm{MPa}$ for the first dry-down cycle and $-1.8 \mathrm{MPa}$ for the second dry-down cycle (i.e., typically a 10 to $16 \mathrm{~d}$ timeframe). Thus, populations were removed from the drought regime one at 





a time. During the recovery period, seedlings from both watering regimes were fertilized with $250 \mathrm{~mL}$ of Plant Products ${ }^{\mathrm{TM}}$ 20-20-20 at $150 \mathrm{ppm} \mathrm{N}$.

\subsection{Measured parameters}

\subsubsection{Gas exchange}

Net $\mathrm{CO}_{2}$ assimilation rate $(A)$, foliar conductance of water vapour $\left(g_{\mathrm{wv}}\right)$ and intrinsic water-use efficiency $\left(\mathrm{WUE}_{i}\right)$ (i.e., ratio of $A$ to $g_{\mathrm{wv}}$ ) were determined using a LI-6400 (LI-COR Inc., Nebraska USA) portable photosynthesis system with the standard sample chamber. Gas exchange was measured on eight seedlings per population and water regime. A section approximating $6 \mathrm{~cm}^{2}$ of foliage area on the upper surface of the third branch from the top of each seedling was tagged for gas exchange measurements. All meristem tips within this foliage section were excised to prevent a change in sample surface area during the experiment, and a non-toxic rubber compound was used to identify the boundary of this sample section. This allowed for repeated measurements on the same foliage section throughout the experiment. Trial measurements did not commence until two weeks after the preparation of this sample area to allow cut tips to heal. At the end of the study, this branch section was removed and the sample's foliage silhouette area was determined with a LI-3000 (LICOR Inc., Nebraska USA) area meter. Surface area was calculated by multiplying the foliage area value by two.

\subsubsection{Predawn shoot water potential}

Predawn shoot water potential $\left(\Psi_{\mathrm{pd}}\right)$ monitored the progression of drought in each population during dry-down cycles. At each measurement period, two gas exchange seedlings and three seedlings from the general population of each family were randomly selected and $\Psi_{\text {pd }}$ measurements were made on excised lower branches. These $\Psi_{\text {pd }}$ measurements were made using a pressure chamber (Soil Moisture Corp. Model 3005) before lights were turned on.

\subsubsection{Water relations parameters}

Osmotic potential at turgor loss point $\left(\Psi_{\text {tlp }}\right)$ and at saturation $\left(\Psi_{\text {sat }}\right)$, relative water content at turgor loss point $\left(\mathrm{RWC}_{\mathrm{tlp}}\right)$, and modulus of cell wall elasticity $\left(\varepsilon_{\max }\right)$ were determined using the pressurevolume shoot-transpiration method with the pressure-volume curves analyzed following procedures of Schulte and Hinckley (1985). Drought avoidance was determined by the rate of water loss from needles after apparent stomatal closure on shoot samples used in the above described pressure-volume analysis (Vanhinsberg and Colombo, 1990). Foliage was separated from the stem portion of each sample after oven-drying to determine dry weight. The rate of water loss in $\mathrm{mg}$ per hour per $\mathrm{g}$ foliage dry weight was determined for each sample. Water loss during the first hour after zero-turgor was defined as apparent transpirational flux density cuticular water loss

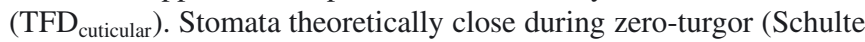
and Hinckley, 1985), thus water loss after zero-turgor was assumed to be primarily through the cuticle.

\subsection{Experimental design and data analysis}

Seedlings from each population (four of the five open-pollinated families as replicates for each population) were placed on light tables in a complete randomized design. Measurements were conducted under well-watered conditions during the day before commencement of dry-down cycles ( $N=8$ seedlings per population). Measurements were made frequently during first dry-down cycle $(N=26$ to 32 paired $\Psi_{\text {pd }}$ and gas exchange measurements per population across the dry-down cycle). Each measurement period during the first dry-down cycle consisted of measurements made on two randomly selected seedlings from eight seedlings tagged for gas exchange in each population. On the fifth day of recovery from the second drought, measurements were once again taken on the sample population $(N=8$ seedlings per population). For the assessment of water relation parameters pre-trial measurements were made on seedlings (one per family, five per population) before dry-down cycles commenced and at the end of the ten day recovery period after exposure to two drydown cycles.

Means and standard errors were calculated for each parameter. One-way analysis of variance was conducted for all parameters to determine population $(P)$ differences before dry-down cycles commenced, and a two-way analysis of variance assessed the fixed effect of drought (i.e., $D=$ well-watered vs. water stress), and the random effect of population on all parameters measured during the second recovery period using SYSTAT Statistical Package, version 9v (SPSS, Inc.). A one-way analysis of variance defined population differences of $\mathrm{RWC}_{\text {tlp }}, \varepsilon_{\mathrm{max}}, \Psi_{\text {sat }} \Psi_{\text {tlp }}$ and $\mathrm{TFD}_{\text {cuticular }}$ (i.e., measured before the drought and only on drought-treated seedlings after two dry-down cycles). If analysis of variance indicated significance, Fisher's least significant difference determined how population means differed. Covariant analysis determined if populations differed in their $A, g_{\mathrm{wv}}$ and $\mathrm{WUE}_{i}$ response to changing $\Psi_{\mathrm{pd}}$ during the first dry-down cycle. A test for homogeneity of slopes of shifting gas exchange parameters in response to $\Psi_{\mathrm{pd}}$ was conducted on log linear values of the above gas exchange parameters, and where slopes differed between populations $(P)$, nonlinear regression analysis modeled these responses. Pearson's product moment correlation coefficient assessed possible relationships between physiological parameter means and various biogeoclimatic site environmental descriptors (defined in Tab. I) for the seven western redcedar populations.

\section{RESULTS AND DISCUSSION}

\subsection{Measured parameters before drought}

The seven western redcedar populations had $A$ that ranged from 3.63 to $5.30 \mu \mathrm{mol} \mathrm{m} \mathrm{m}^{-2} \mathrm{~s}^{-1}, g_{\mathrm{wv}}$ that ranged from 72.6 to $90.5 \mathrm{mmol} \mathrm{m}^{-2} \mathrm{~s}^{-1}$ and $\mathrm{WUE}_{i}$ from 0.048 to $0.055 \mu \mathrm{mol}$ $\mathrm{CO}_{2} \mathrm{mmol}^{-1} \mathrm{H}_{2} \mathrm{O}$ under well-watered conditions (Fig. 1). These gas exchange values are comparable to reported values for western redcedar under field conditions (Grossnickle, 1993; Grossnickle et al., 2005). There was variation $(P>0.05)$ in the gas exchange response for various populations. The Gaibaldi population (\#11) had the greatest and the Kennedy Lake (\#12) the lowest $A$ and $g_{\mathrm{wv}}$, while the Nicolum population (\#4) had the greatest, with Yellowpoint (\#2) and Creston (\#23) the lowest $\mathrm{WUE}_{i}$. Fan et al. (2008) reported these western redcedar populations to have no variation in $g_{\mathrm{wv}}$ and $\mathrm{WUE}_{i}$ 

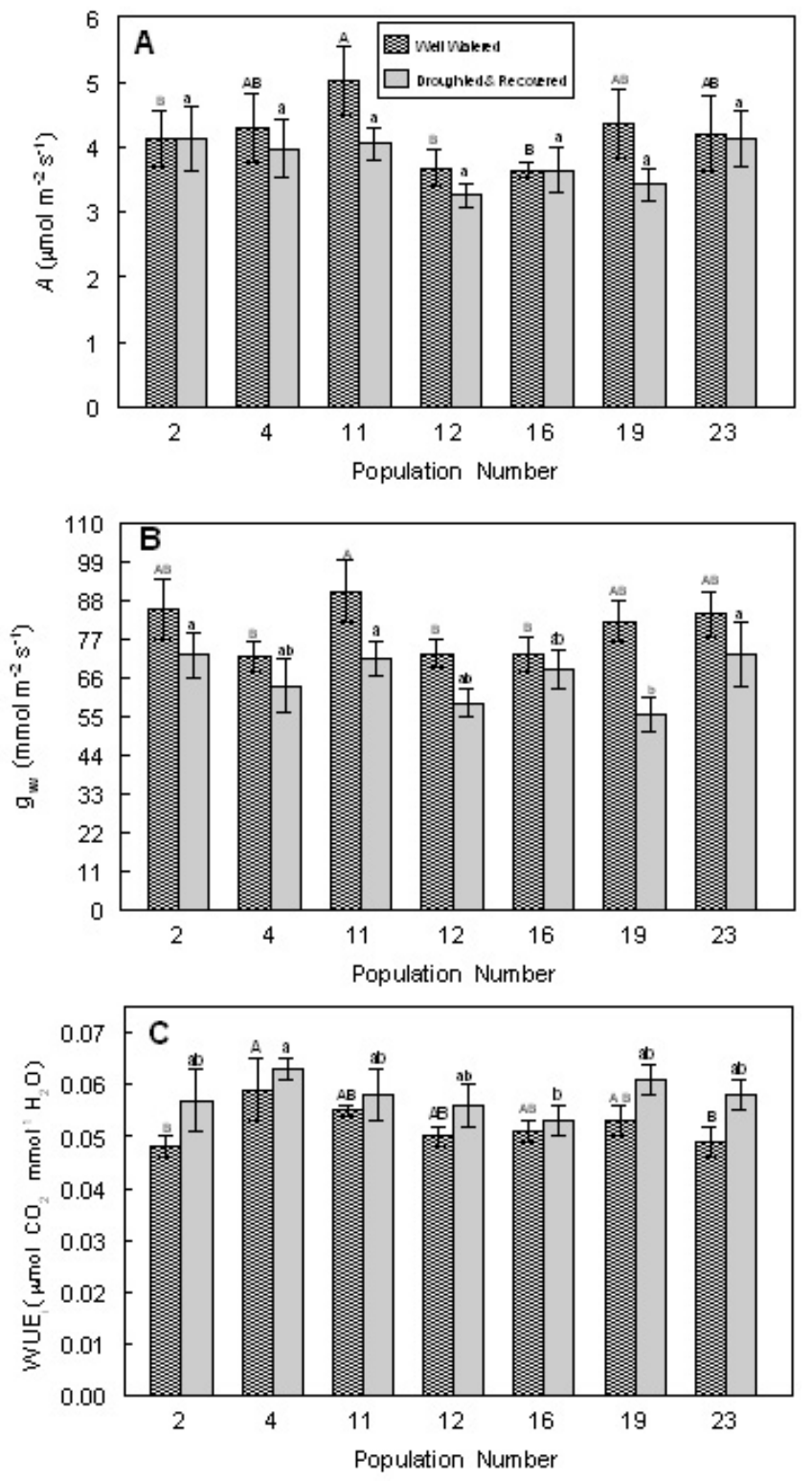

Figure 1. Mean (SE) for net $\mathrm{CO}_{2}$ assimilation $(A)$, stomatal conductance of water vapour $\left(g_{\mathrm{wv}}\right)$ and intrinsic water use efficiency $\left(\mathrm{WUE}_{i}\right)$ for well-watered seedlings and well-watered seedlings after two drydown cycles from seven western redcedar populations. Population means for each parameter that do not share the same letter (uppercase for well-watered \& lower case for drought recovery) are significantly different $(P<0.05$ Fisher's LSD test). See Table I for population details.

under well-watered conditions, while under forest site conditions the two populations from Vancouver Island (Yellowpoint \#2 \& Kennedy Lake \#12) had greater $A$ and $g_{\mathrm{wv}}$, across a full range of vapor deficit conditions (Grossnickle et al., 2005). Varying gas exchange response patterns for the same western redcedar populations under a range of test conditions indicates that instantaneous gas exchange parameters are not a definitive means to define population performance differences.
Water relations parameters had the following range of values: $81.9 \%$ to $86.8 \%$ for $\mathrm{RWC}_{\text {tlp }}, 6.1 \mathrm{MPa}$ to $8.8 \mathrm{MPa}$ for $\varepsilon_{\max },-1.235 \mathrm{MPa}$ to $-0.995 \mathrm{MPa}$ for $\Psi_{\text {sat }}$ and $-1.456 \mathrm{MPa}$ to $-1.336 \mathrm{MPa}$ for $\Psi_{\text {tlp }}$ (Tab. II). The ranges of these water relation parameters are comparable to reported values for actively growing western redcedar under field conditions (Grossnickle, 1993). Population differences were detected only in $\mathrm{RWC}_{\mathrm{tlp}}$, with the Niclolum population (\#4) having greater $\mathrm{RWC}_{\text {tlp }}$ than all other populations, except Gilipin (\#19).

\subsection{Gas exchange during drought}

During drought, $A$ (Fig. 2) and $g_{\mathrm{wv}}$ (not shown) declined with decreasing $\Psi_{\text {pd }}$. This is a typical gas exchange pattern for western redcedar to decreasing soil water under field conditions (Grossnickle, 1993). Analysis of gas exchange response to decreasing $\Psi_{\mathrm{pd}}$ indicated that the seven populations differed in their $A$ response $(P \leq 0.05)$ to changing $\Psi_{\mathrm{pd}}$, with the Garibaldi population (\#11) having the least change in $A$ and the Kennedy Lake population (\#12) having the largest decline in $A$ to decreasing $\Psi_{\mathrm{pd}}$. Genetic variation in the response of $A$ to changing plant water status has been found to be a common occurrence (e.g., Grossnickle and Fan, 1999; Major and Johnsen, 1996; Russell, 1993). All populations were similar in their $g_{\mathrm{wv}}$ and $\mathrm{WUE}_{i}$ response to decreasing $\Psi_{\mathrm{pd}}$ (not shown). Fan et al. (2008) reported a similar pattern of $g_{\mathrm{wv}}$ and $\mathrm{WUE}_{i}$ response for these same populations under long-term moderate drought, with a similar lack of genotypic variation in these gas exchange parameters reported for other tree species (Major and Johnsen, 1996; Parker and Pallardy, 1991).

\subsection{Post drought gas exchange}

After drought, all populations had a similar $A$ response during recovery from drought (Fig. 1). Population differences were detected for $g_{\mathrm{wv}}$ (Yellowpoint [\#2], Garibaldi [\#11] and Creston [\#23] which were greater than Gilpin [\#19]) and $\mathrm{WUE}_{i}$ (Nicolum [\#4] was greater than Oliver Lake [\#16]). Fan et al. (2008) reported that the same western redcedar populations had comparable gas exchange patterns under drought due to the overall suppression effect of drought. Thus, western redcedar populations express minor variation during actual drought conditions, though they can express variation in instantaneous gas exchange response during recovery from drought.

\subsection{Water relations after drought}

Western redcedar populations showed a change in water relations parameters in response to drought; $\mathrm{RWC}_{\mathrm{tlp}}, \Psi_{\mathrm{tlp}}$ and $\Psi_{\text {sat }}$ decreased, while $\varepsilon_{\max }$ remained relatively unchanged (Tab. II). This is a typical pattern of increased drought tolerance for western redcedar in response to drought (Major et al., 1994). Osmotic adjustment was greatest in the Creston and Gilpin populations (\#23 \& \#19, respectively) for $\Psi_{\text {tlp }}$, and the 


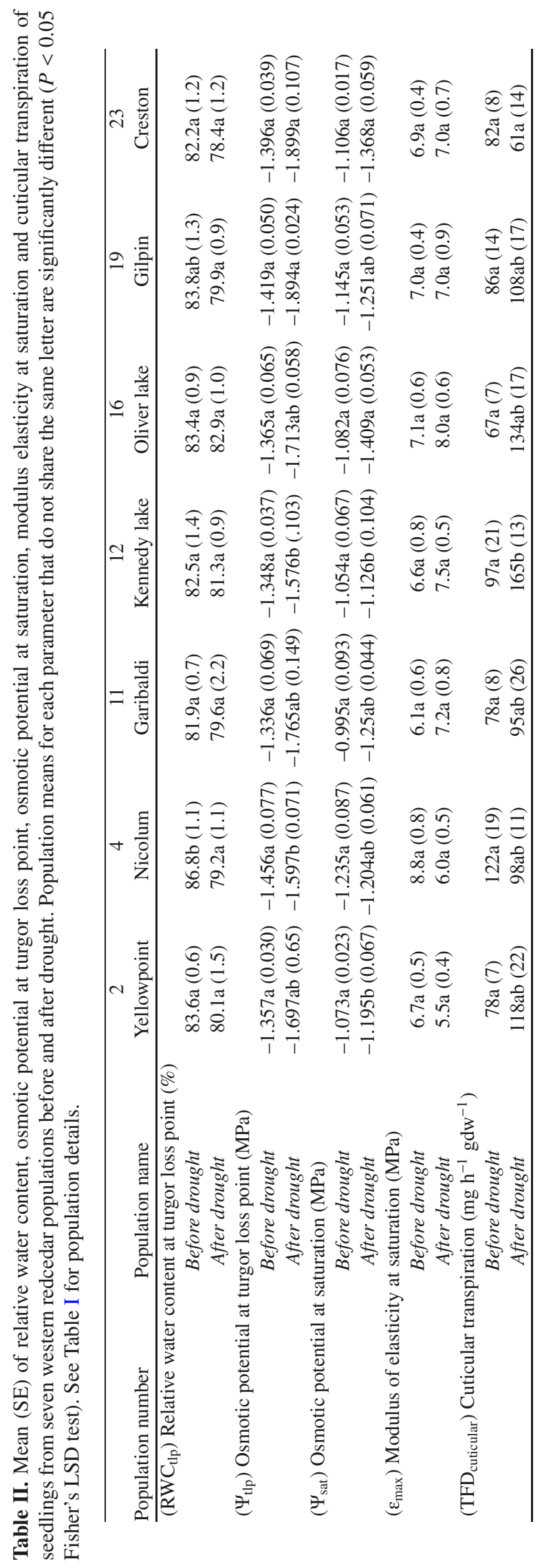




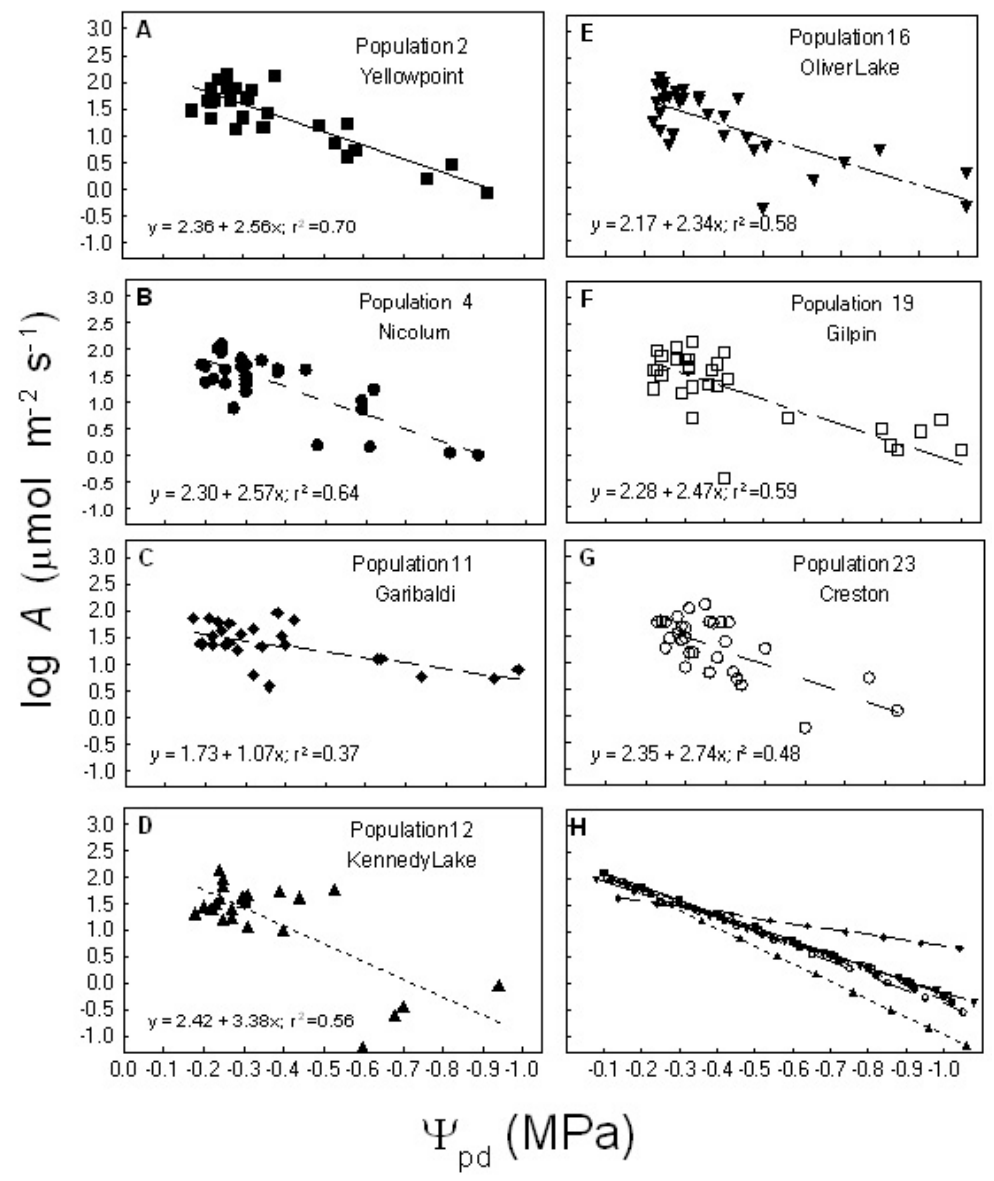

Figure 2. The relationship between $\log$ transformed net $\mathrm{CO}_{2}$ assimilation $(A)$ and predawn shoot water potential $\left(\Psi_{\text {pd }}\right)$ for seven western redcedar seedling populations during drought. Individual populations are shown in sections A to G, and all populations are shown together in section H. See Table I for population details.

Creston and Oliver Lake populations (\#23 \& \#16) for $\Psi_{\text {sat }}$. There were no population differences for $\mathrm{RWC}_{\mathrm{tlp}}$ and $\varepsilon_{\max }$ in response to drought. Genetic variation in osmotic adjustment within a species can occur in response to drought (e.g., Abrams, 1988; Aspelmeier and Leuschner, 2004; Johnsen and Major, 1999; Russell, 1993). In the current study, western redcedar populations provided evidence of genetic variation in drought tolerance to short-term drought.

Drought avoidance was determined by measuring apparent cuticular water loss. Cuticular transpiration ( $\mathrm{TFD}_{\text {cuticular }}$ ) increased across all populations by $\sim 25 \%$ after drought (Tab. II). The supposition was that $\mathrm{TFD}_{\text {cuticular }}$ should decline in tested western redcedar populations after exposure to drought because of the increase in wax structures that can occur on western redcedar foliage after drought (Krasowski and Owens, 1991). However, cuticular water loss increases during shoot elongation (Grossnickle and Folk, 2007; Vanhinsberg and Colombo, 1990) and though these western redcedar seedlings were being exposed to drought, they did show continued shoot growth during the trial (data not shown). For TFD $_{\text {cuticular the }}$ Creston population (\#23) had the lowest values while the Kennedy Lake population (\#12) had the highest values. Ge- netic variation in $\mathrm{TFD}_{\text {cuticular }}$ has been detected in other tree species (Grossnickle and Folk, 2007).

\subsection{Physiological adaptations to habitat}

Gas exchange parameters measured on these western redcedar populations had few significant correlations with climatic indices (Tab. III). The exception to this was with $\mathrm{WUE}_{i}$ that showed a relationship to continentality (Fig. 3) after exposure to drought. In contrast, correlations were found with climatic indices for these western redcedar populations and a number of the water relation parameters after seedlings were exposed to drought (i.e., $\mathrm{RWC}_{\text {tlp }}, \varepsilon_{\max }, \Psi_{\text {tlp }}$ and $\mathrm{TDF}_{\text {cuticular }}$ ). Continentality was significantly correlated with the greatest number of water relations parameters (Tab. III and Fig. 3) such that populations from more interior locations had greater drought tolerance $\left(\mathrm{RWC}_{\text {tlp }}, \Psi_{\text {tlp }}\right)$, drought avoidance $\left(\mathrm{TDF}_{\text {cuticular }}\right)$ and greater water use efficiency $\left(\mathrm{WUE}_{i}\right)$ than coastal populations. Water relations parameters for these western redcedar populations were also related to site precipitation characteristics (i.e., mean annual precipitation (MAP) and 


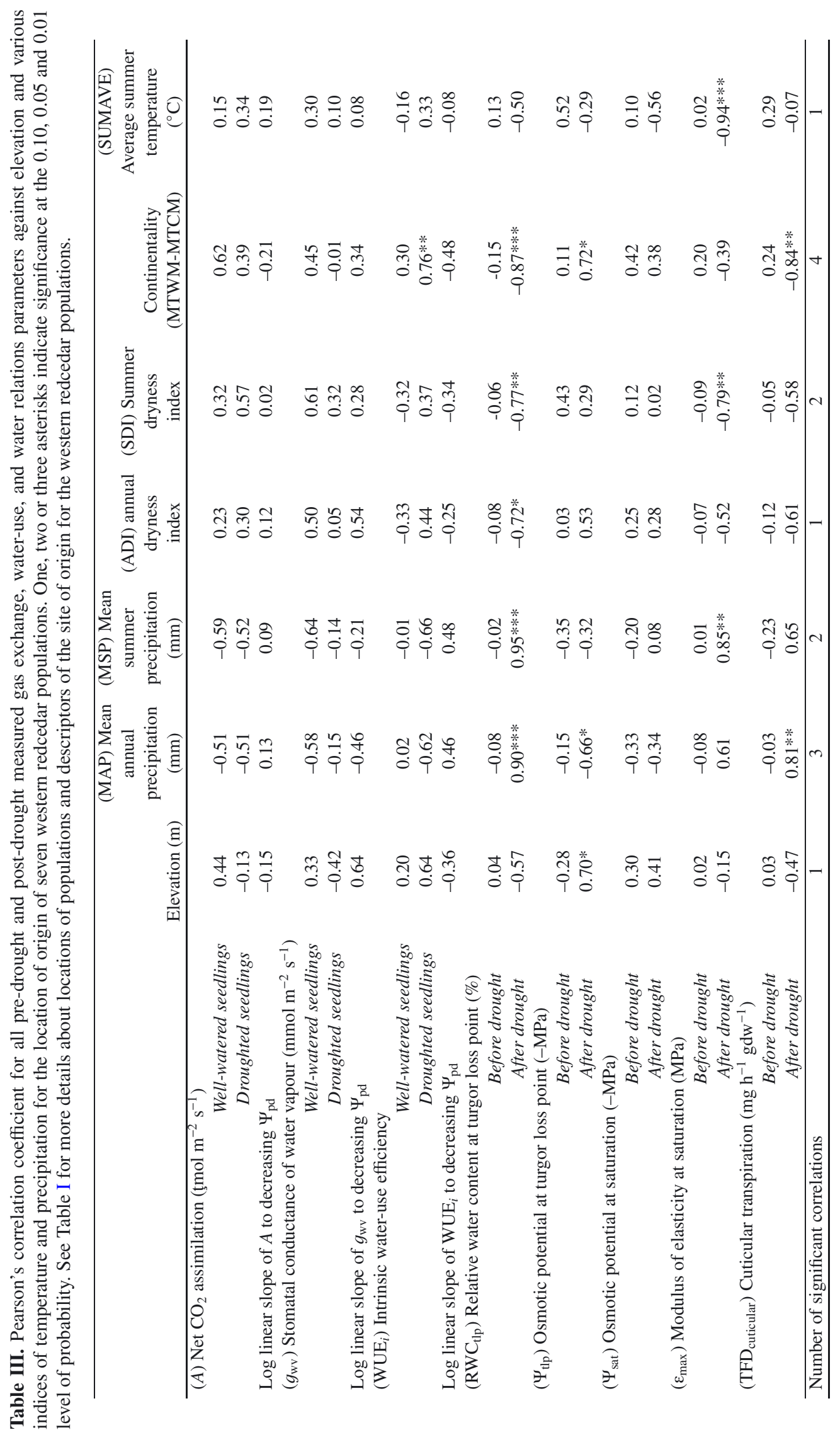





Figure 3. Relationship of seven western cedar populations after exposure to drought with continentality (A) relative water content at turgor loss point $\left(\mathrm{RWC}_{\text {tlp }}\right),(\mathrm{B})$ osmotic potential at turgor loss point $\left(\Psi_{\text {tlp }}\right),(\mathrm{C})$ cuticular transpiration $\left(\mathrm{TFD}_{\text {cuticular }}\right)$ and (D) intrinsic water use efficiency $\left(\mathrm{WUE}_{i}\right)$; mean summer precipitation with $(\mathrm{E})$ relative water content at turgor loss point $\left(\mathrm{RWC}_{\mathrm{tlp}}\right)$ and $(\mathrm{F})$ modulus elasticity at saturation $\left(\varepsilon_{\max }\right)$; annual precipitation with $(\mathrm{G})$ osmotic potential at turgor loss point $\left(\Psi_{\text {tlp }}\right)$ and $(\mathrm{H})$ cuticular transpiration $\left(\mathrm{TFD}_{\text {cuticular }}\right)$. The $r$ is Pearson's correlation coefficient, and the line provides a visual assessment of qualitative trends in the data. Table I describes more details of environmental indices.

mean summer precipitation); with populations from drier sites having a lower $\mathrm{RWC}_{\mathrm{tlp}}$, higher $\varepsilon_{\mathrm{max}}$, more negative $\Psi_{\text {tlp }}$ and lower $\mathrm{TDF}_{\text {cuticular }}$ compared to populations from wetter sites. Genetic variation in gas exchange and water relation parameters can be related to habitat from which a tree species have originated (e.g., Aspelmeier and Leuschner, 2004; Parker and Pallardy, 1985). This trial shows that western redcedar populations from drier-inland habitats had greater development of drought tolerance, avoidance as well as water use efficiency in response to drought than populations from coastal origin with temperate maritime habitats.

Plants respond to environmental variability through physiological adaptation (Bazzaz, 1996) and genetic adaptability to drought can be expressed by a plants ecophysiological response. By defining the physiological response of a species to site environmental conditions, one provides a means to 
understand the biological basis for the adaptability of tree species to site (Dickmann, 1992). A series of trials were conducted to define the response of a group of western redcedar populations originating from coastal to interior biogeoclimatic subzones where summer time environmental conditions can impose a range of drought conditions. Combined results of these trials have found that western redcedar populations from more interior sites with drier summer habitats tended to have greater capability to develop drought tolerance, drought avoidance and instantaneous water use efficiency in response to short term drought (current trial). However, these western cedar populations did not show adaptation to summer climatic conditions related to long term water use efficiency and summer seasonal gas exchange response to vapor pressure deficit (Grossnickle et al., 2005), as well as growth under a range of extended soil water conditions (Fan et al., 2008).

Substantial shifts in potential forest tree species habitats under current climate change predictions may result in more favorable ecosystems that can support western redcedar (Hamann and Wang, 2006). As well, climate-based seed transfer is currently being implemented in British Columbia (O’Neill et al., 2008) and assisted migration will most likely become more important to ensure future resilient forests. Western redcedar population movements beyond both current seed transfer guidelines and present species distribution can benefit from a sound gene resource management program that entails both long-term field trials as well as controlledenvironment studies such as reported in this paper. Information from this and other studies will help to identify important western redcedar population adaptation patterns to present and future selection pressures.

\section{CONCLUSIONS}

Development of drought tolerance and avoidance capability, in response to drought, was found to occur among seven western redcedar populations originating along a precipitation gradient (from east to west) from various biogeoclimatic zones in British Columbia. In contrast, there were minimal population differences in the gas exchange response to drought. Combined results from a series of trials on the same western redcedar populations found that water relations parameters were a better physiological measure than growth, gas exchange response and long term water use efficiency to identify population adaptability to summer climatic conditions. Physiological response patterns of this wide array of western redcedar populations can provide information for developing a sound gene resource management strategy that includes gene conservation, seed movement and tree breeding.

\section{REFERENCES}

Abrams M.D., 1988. Sources of variation in osmotic potentials with special reference to North American tree species. For. Sci. 34: 10301046.

Aspelmeier S. and Leuschner C., 2004. Genotypic variation in drought response of silver birch (Betula pendula): leaf water status and carbon gain. Tree Physiol. 24: 517-528.
Bazzaz F.A., 1996. Plants in changing environments. Cambridge University Press, Cambridge, $330 \mathrm{p}$.

Daly C., Taylor G., and Gibson W., 1997. The PRISM Approach to Mapping Precipitation and Temperature. In: 10th Conf. on Applied Climatology, Reno, NV, Amer. Meteor. Soc., pp. 10-12.

Dickmann D., 1992. Role of physiology in forest tree improvement. Silva Fenn. 25: 248-256.

Fan S., Grossnickle S.C., and Russell J.H., 2008. Morphological and physiological variation in western redcedar (Thuja plicata Donn Ex D. Don) populations under contrasting soil water conditions. Trees 22: 671-683.

Green R.N., Courtin P.J., Klinka K., Slaco R.J., and Ray C.A., 1984. Site diagnosis, tree species selection, and slashburning guidelines for the Vancouver Forest Region. Land Manage. Handb. No. 8, British Columbia Ministry of Forests, Victoria, B.C., 143 p.

Grossnickle S.C., 1993. Shoot water relations and gas exchange of western hemlock and western red cedar seedlings during establishment on a reforestation site. Trees, 7: 148-155.

Grossnickle S.C. and Fan S., 1999. Genetic variation in response to drought of interior spruce (Picea glauca (Moench) Voss x P. engelmannii Parry ex engelm.). Scand. J. For. Res. 14: 240-250.

Grossnickle S.C. and Folk R.S., 2007. Field performance potential of a somatic interior spruce seedlot. New For. 34: 51-72.

Grossnickle S.C., Fan S., and Russell J.H., 2005. Variation in gas exchange and water use efficiency patterns among populations of western redcedar. Trees 19: 32-42.

Guy R.D. and Holowachuk D.L., 2001. Population differences in stable carbon isotope ratio of Pinus contorta Dougl. ex Loud: relationship to environmental, climate of origin, and growth potential. Can. J. Bot. 79: 274-283.

Hamann A. and Wang T.L., 2006. Potential effects of climate change on tree species and ecosystem distribution in British Columbia. Ecology 87: 2773-2786.

Hope G.D., Mitchell W.R., Lloyd D.A., Erickson W.R., Harper W.L., and Wikeem B.M., 1991. Interior-Douglas-fir zone. In: Meidinger D. and Pojar J. (Eds.), Ecosystems of British Columbia. British Columbia Ministry of Forests, Special Report No. 6, pp. 153-166.

Johnsen K.H. and Major J.E., 1995. Gas exchange of 20-year-old black spruce families displaying a genotype $\mathrm{x}$ environment interaction in growth rate. Can. J. For. Res. 25: 430-439.

Johnsen K.H. and Major J.E., 1999. Shoot water relations of mature black spruce families displaying a genotype $\mathrm{x}$ environment interaction in growth rate. I. Family and site effects over three growing seasons. Tree Physiol. 19: 367-374.

Ketcheson M.V., Braumandl T.F., Meidinger G., Utzig G., Demarchi D.A., and Wikeem B.M., 1991. Interior cedar - Hemlock Zone. In: Meidinger D. and Pojar J. (Eds.), Ecosystems of British Columbia. British Columbia Ministry of Forests, Special Report No. 6, pp. 167182.

Krasowski M.J. and Owens J.N., 1991. Growth and morphology of western red cedar seedlings as affected by photoperiod and moisture stress. Can. J. For. Res. 21: 340-352.

Lloyd D.K., Angrove K., Hope G., and Thompson C., 1990. A guide for site identification and interpretation of the Kamloops Forest Region. Vols. 1 and 2, Land Manage. Handb. No. 23, British Columbia Ministry of Forests, Victoria, B.C., 399 p.

Major J.E. and Johnsen K.H., 1996. Family variation in photosynthesis of 22-year-old black spruce: a test of two models of physiological response to water stress. Can. J. For. Res. 26: 1922-1933.

Major J.E., Grossnickle S.C., Folk R.S., and Arnott J.T., 1994. Influence of nursery culture on western redcedar. I. Measurement of seedling attributes before fall and spring planting. New For. 8: 211-229.

Meidinger D. and Pojar J., 1991. Ecosystems of British Columbia. British Columbia Ministry of Forests, Victoria, B.C., Special Rep. No. 6, pp. 9-38, 81-112, 153-182. 
Minore D., 1990. Thuja plicata Donn ex D. Don, Western Redcedar. In: Burns R.M., Honkala B.H. (Compilers), Silvics of North America: 1. Conifers, Agriculture Handbook 654. US Department of Agriculture, Forest Service, Washington, D.C., Vol. 1, pp. 590-600.

Monson R.K. and Grant M.C., 1989. Experimental studies of ponderosa pine. III. Differences in photosynthesis, stomatal conductance, and water-use efficiency between two genetic lines. Am. J. Bot. 76: 10411047.

Nuszdorfer F.C., Klinka K., and Demarchi D.A., 1991. Coastal Douglasfir zone. In: Meidinger D. and Pojar J. (Eds.), Ecosystems of British Columbia. British Columbia Ministry of Forests, Special Report No. 6, pp. 81-94.

O'Connell L.M., Viard F., Russell J., and Ritland K., 2001. The mating system in natural populations of western redcedar (Thuja plicata). Can. J. Bot. 79: 753-756.

O’Neill G.A., Ukrainetz N.K., Carlson M.R., Cartwright C.V., Jaquish B.C., King J.N., Krakowski J., Russell J.H., Stoehr M.U., Xie C., and Yanchuk A.D., 2008. Assisted migration to address climate change in British Columbia: recommendations for interim seed transfer standards. B.C. Min. For. Range, Res. Br., Victoria, B.C. Tech. Rep. 048. www.for.gov.bc.ca/hfd/pubs/Docs/Tr/Tr048.htm

Parker W.C. and Pallardy S.G., 1985. Genotypic variation in tissue water relations of leaves and roots of black walnut Juglans nigra seedlings. Physiol. Plant. 64: 105-110.

Parker W.C. and Pallardy S.G., 1991. Gas exchange during a soil drying cycle in seedlings of four black walnut Juglans nigra families. Tree Physiol. 9: 339-348.
Pojar J., Meidinger D.V., and Klinka K., 1991. Concepts. In: Meidinger D. and Pojar J. (Eds.), Ecosystems of British Columbia. British Columbia Ministry of Forests, Special Report No. 6, pp. 9-38.

Rehfeldt G.E., 1994. Genetic structure of western redcedar populations in the Interior West. Can. J. For. Res. 24: 670-680.

Russell J.H., 1993. Genetic architecture, genecology and phenotypic plasticity in seed and seedling traits of yellow cedar (Chamaecyparis nootkatensis (D. Don) Spach). Dissertation, Univ. of British Columbia.

Russell J.H., Burdon R.B., and Yanchuk A.D., 2003. Inbreeding depression and variance structures for height and adaptation in self- and outcross Thuja plicata families in varying environments. For. Gen. 10: $171-184$.

Schulte P.J. and Hinckley T.M., 1985. A comparison of pressure-volume curve data analysis techniques. J. Exp. Bot. 36: 1590-1602.

Van Eerden E. and Gates J.W., 1990. Seedling production and processing: container. In: Lavender D.P., Parish R., Johnson C.M., Montgomery G., Vyse A., Willis R.A., and Winston D. (Eds.), Regenerating British Columbia's forests. Univ. of British Columbia Press, Vancouver, B.C., pp. 226-234.

Vanhinsberg N.B. and Colombo S.J., 1990. Effect of temperature and needle anatomy and transpiration of Picea mariana after bud set. Can. J. For. Res. 20: 598-601.

Wang T. and Russell J.H., 2006. Evaluation of selfing effects on western redcedar growth and yield in operational plantations using the tree and stand simulator (TASS). For. Sci. 281-289.

Yeh F.C., 1988. Isozyme variation of Thuja plicata (Cupressaceae) in British Columbia. Biochem. Syst. Ecol. 16: 373-377. 